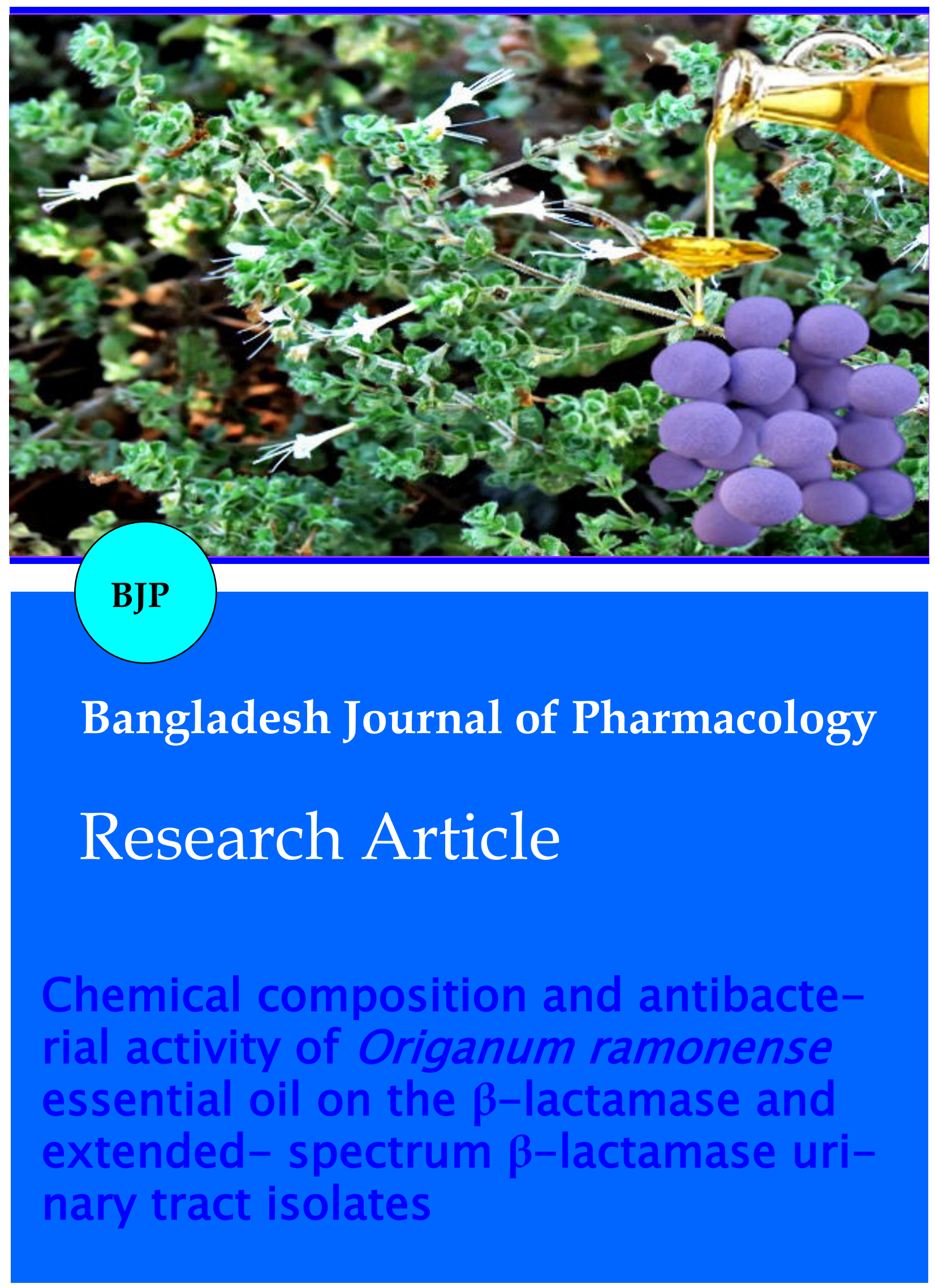




\title{
Chemical composition and antibacterial activity of Origanum ramonense essential oil on the $\beta$-lactamase and extended- spectrum $\beta$-lactamase urinary tract isolates
}

\author{
Haitham N. Qaralleh
}

Department of Medical Laboratory Sciences, Mutah University, Mu’tah, Karak 61710, Jordan.

\begin{tabular}{|l|}
\hline Article Info \\
\hline Received: $\quad$ J June 2018 \\
Accepted: $\quad$ 9 September 2018 \\
Available Online: 21 September 2018 \\
DOI: 10.3329/bjp.v13i3.36897 \\
\\
\\
\\
Cite this article: \\
Qaralleh H. Chemical composition \\
and antibacterial activity of Origanum \\
ramonense essential oil on the $\quad \beta$ - \\
lactamase and extended-spectrum $\beta$ - \\
lactamase urinary tract isolates. Bang- \\
ladesh J Pharmacol. 2014; 9: 280-86.
\end{tabular}

\begin{abstract}
The aim of this study was to evaluate the antibacterial activity of Origanum ramonense essential oil extracted from the air-dried leaves against $\beta$-lactamase and extended-spectrum $\beta$-lactamase obtained from the patients with urinary tract infection. The essential oil was extracted by hydrodistillation and analyzed by GC-MS. In vitro antibacterial activity was studied using disc diffusion and micro-dilution methods. Twenty compounds were identified representing $97.8 \%$ of the total oil. The major components were carvacrol $(84.6 \%)$, p-cymene $(4.3 \%)$ and $\gamma$-terpinene $(3.3 \%)$. The oil showed a broad spectrum of antibacterial activity against all tested isolates. Staphylococcus aureus, S. epidermidis, Klebsiella pneumoniae and Enterobacter aerogenes had the lowest minimum inhibitory concentration values $(0.015 \mu \mathrm{g} / \mathrm{mL})$ followed by Escherichia coli $(0.14 \mu \mathrm{g} / \mathrm{mL})$. The lowest susceptible strains to oil were Pseudomonas aeruginosa, Proteus mirabilis, E. coli 25922 and P. aeruginosa 10145. The bacteriostatic and bactericidal effects at concentrations as low as 0.015 $\mu \mathrm{g} / \mathrm{mL}$ indicated the potent antibacterial activity of $O$. ramonense.
\end{abstract}

\section{Introduction}

Urinary tract infection is one of the most common and highly recurrent bacterial infections. The most prevailing bacteria which are responsible is the Escherichia coli. Many other urinary tract infection-causing genera are also isolated from the patients with a variable degree of infection such as Klebsiella, Enterobacter, Proteus, Serratia and Pseudomonas aeruginosa (Al-Asoufi et al., 2017).

However, a significant number of infections caused by multidrug-resistant bacteria among urinary tract infection patients, such as the extended $\beta$-lactamaseresistant bacteria, have been reported (Bartoletti et al., 2016). For instance, antimicrobial resistance survey on cystitis showed that a high percentage of E. coli strains were ampicillin, trimethoprim/sulfamethoxazole and nalidixic acid resistant strains while $K$. pneumoniae strains were mecillinam, fosfomycin, cefuroxime and nitrofurantoin resistant (Schito et al., 2009). In addition, $12 \%$ of patient with UPEC urinary tract infection had fluoroquinolone-resistant isolates (Van der Starre et al., 2010). The increasing prevalence of urinary tract infection isolates that were resistant to routinely used antibiotics, particularly to beta-lactams or extendedspectrum beta-lactamase, has stimulated interest in finding new and effective antimicrobial agents from other sources such as plants.

Essential oils have been applied for centuries in pharmaceuticals and alternative medicine. They are effective as antibacterial, antifungal, antiviral, anti-inflammatory, anti-oxidant, and as anti-cancer (Bakkali et al., 2008; Tarawneh et al., 2010; Benelli et al., 2017; Burt, 2004; Martinelli et al., 2017). Essential oils are secondary metabolites produced by aromatic plant families such as Apiaceae and Lamiaceae. They are the mixture of 
terpenes (monoterpenes and sesquiterpenes), terpenoids (isoprenoids), and aliphatic and aromatic compounds including aldehydes and phenols (Sakkas and Papadopoulou, 2017).

Origanum is a genus that includes 54 species in the family Lamiaceae. Traditionally, decoction of leaves and stems as well as their essential oils are widely used as remedies of upper respiratory and digestive complaints such as cough, sore throat and gastric spasm. Generally, the ability of Origanum species to inhibit the growth of pathogenic bacteria has been investigated in numerous studies. Reports showed that Origanum essential oil possesses potential antibacterial activity with low minimum inhibitory concentration and minimum bactericidal concentration (Bassanetti et al., 2017; Carezzano et al., 2017; Habbadi et al., 2017; Özkan et al., 2017). Therefore, they can be a powerful tool to reduce the impact of bacterial drug resistance issue.

To the best of our knowledge, this is the first report on the antibacterial effect and the second one about the chemical composition of $O$. ramonense essential oil. Thus, the aims of this study are to evaluate the antibacterial activity of essential oil extract from the $O$. ramonense leaves against $\beta$-lactamase and extendedspectrum $\beta$-lactamase obtained from patients with urinary tract infection symptoms and to survey the chemical constituents of the essential oil extract of Jordan habitat $O$. ramonense dried leaves.

\section{Materials and Methods}

\section{Plant materials}

Areal parts of O. ramonense were collected from Aye region, Al-Karak Province, south of Jordan during March to April 2017. The plant was identified by Dr. Feryal Al-Khresat (Department of Biology, Mu'tah University, Al-Karak, Jordan) according to flora Palaestina, part 3. Voucher specimen had been deposited in the Department of Medical Laboratory Sciences, Faculty of Science, Mu'tah University, AlKarak, Jordan.

The freshly collected materials were air dried at room temperature in the shade and then the leaves were separated from the stem and subjected to essential oil extraction.

\section{Essential oil extraction}

Sample of $150 \mathrm{~g}$ of the dried leaves was subjected to hydrodistillation using simple Clevenger apparatus for 4 hours. The oil was extracted from the aqueous phase using n-hexane and dried over anhydrous sodium sulfate $\left(\mathrm{Na}_{2} \mathrm{SO}_{4}\right)$. Finally, the extracted oil was stored as aliquots at $4^{\circ} \mathrm{C}$.
Gas chromatography-mass spectrometry (GC-MS) analysis

GC-MS analysis was performed using Varian chrompack CP-3800 GC-MS-MS-200 equipped with split-splitless injector, DB-5 GC column and the mass detector was set to scan ions between $40-400 \mathrm{~m} / \mathrm{z}$ using full scan mode and electron impact (EI, $70 \mathrm{eV})$. The parameters and conditions used in this test were similar to that used by (Tawaha et al., 2015). A hydrocarbon mixture of n-alkanes (C8-C20) was analyzed separately by GC-MS using the same column (DB-5) and under the same chromatographic conditions. The compounds were identified by comparison of their retention time to $\mathrm{n}$-alkaline retention times and their similarities to mass spectra database (NIST library) and published reports.

\section{Antibacterial activity}

\section{Bacterial strains}

Seven clinical isolates were used in this study including five Gram negative strains: Extended-spectrum $\beta$ lactamase producing E. coli, extended-spectrum $\beta$ lactamase producing Proteus mirabilis, $\beta$-lactamase producing $K$. pneumoniae, $\beta$-lactamase producing Pseudomonas aeruginosa and E. aerogenes, and two Gram positive strains: $\beta$-lactamase producing Staphylococcus aureus and S. epidermidis.

The clinical isolates were obtained from the Al-Salam Specialty Hospital (Al-Karak, Jordan) and Al Bashir Hospital (Amman, Jordan). These strains were isolated from patients with urinary tract infection symptoms and they were characterized by BIOMÉRIEUX VITEK $®$ 2 SYSTEM or by Enterosystem $18 \mathrm{R}$ (Liofilchem). In addition, two reference strains: E. coli 25922 and $P$. aeruginosa 10145 provided by Dr. Wael Al-Zereini (Department of Biology, Mu'tah University, Al-Karak, Jordan) were used.

\section{Disc diffusion method}

The disc diffusion method was performed as previously described (Qaralleh et al., 2010) with some modifications. Briefly, $100 \mu \mathrm{L}$ of a bacterial suspension containing $1.5 \times 10^{8} \mathrm{CFU} / \mathrm{mL}$ (0.5 McFarland's standard) was spread using a sterile swab on Mueller-Hinton agar plates. Then, sterile blank discs containing $3 \mu \mathrm{L}$ essential oil or ciprofloxacin $(5 \mu \mathrm{g})$ were placed onto the inoculated plates. The plates were incubated at $37^{\circ} \mathrm{C}$ for 24 hours. Each test was performed in triplicate and the zone of inhibition was measured as millimeter diameter.

\section{Minimum inhibitory concentration and minimum bactericidal concentration}

The minimum inhibitory concentration was measured using the microdilution method with some modifications (Qaralleh et al., 2010). Three-fold dilution was 
prepared using 96 well plats from a stock solution of 10 $\mu \mathrm{g}$ essential oil in $10 \%$ DMSO solvent. Then $10 \mu \mathrm{L}$ of bacterial suspension containing $1.5 \times 10^{8} \mathrm{CFU} / \mathrm{mL}(0.5$ McFarland's standard) was inoculated into each well. The same test was carried out with $10 \%$ DMSO as a control. Each test was performed in triplicate. The lowest concentration of essential oil needed to inhibit the visible growth of the tested microbes after 24 hours was considered as the minimum inhibitory concentration value.

The minimum bactericidal concentration was determined by sub-culturing and spreading the wells content with concentrations of equal to and higher than the minimum inhibitory concentration value on agar plate. The lowest concentration of essential oil that exhibited no growth on the agar plate after incubation at $37^{\circ} \mathrm{C}$ for 24 hours was reported as the minimum bactericidal concentration.

\section{Results}

Based on the dry weight of the plant, the obtained yield of the essential oil was determined as $0.9 \%(\mathrm{v} / \mathrm{w})$.
The chromatogram of GC-MS (Figure 1) showing the chemical constituents of the essential oil extracted from air-dried leaves of $O$. ramonense identified 20 compounds comprising $97.8 \%$ of the total oil (Table I). The oil was characterized by a large amount of ooxygenated monoterpenes $(86.9 \%)$ followed by monoterpenes hydrocarbons $(9.8 \%)$. The carvacrol $(84.6 \%)$, p-cymene $(4.3 \%)$ and $\gamma$-terpinene $(3.3 \%)$ were the major components. The other compounds such as a-thujene, $\beta$ pinene, a-terpinene, cis-sabinene hydrate, terpinen-4-ol, thymol, 5-methoxy-1, 2, 3-trimethylbenzene and caryophyllene, which were ranged from 0.96 to $0.36 \%$. The oil had lower contents of linalool, cis-dihydrocarvone, carvotanacetone, a-phellandrene, geranial, a-humulene, $\gamma$-cadinene, caryophyllene oxide and $\delta$-cadinene (less than $0.26 \%$ each).

The essential oil clearly showed inhibition activity against all tested bacteria (Table II). The results of disc diffusion method using $O$. ramonense essential oil showed that $S$. aureus, S. epidermidis and E. coli were the most sensitive clinical isolates with inhibition zones of 28.3, 26.2 and $24.5 \mathrm{~mm}$, respectively followed by $E$. aerogenes, P. aeruginosa and K. pneumoniae $(21.3,20.7$ and $20.2 \mathrm{~mm}$, respectively). While $P$. mirabilis exhibited the smallest inhibition zone $(16.7 \mathrm{~mm})$.

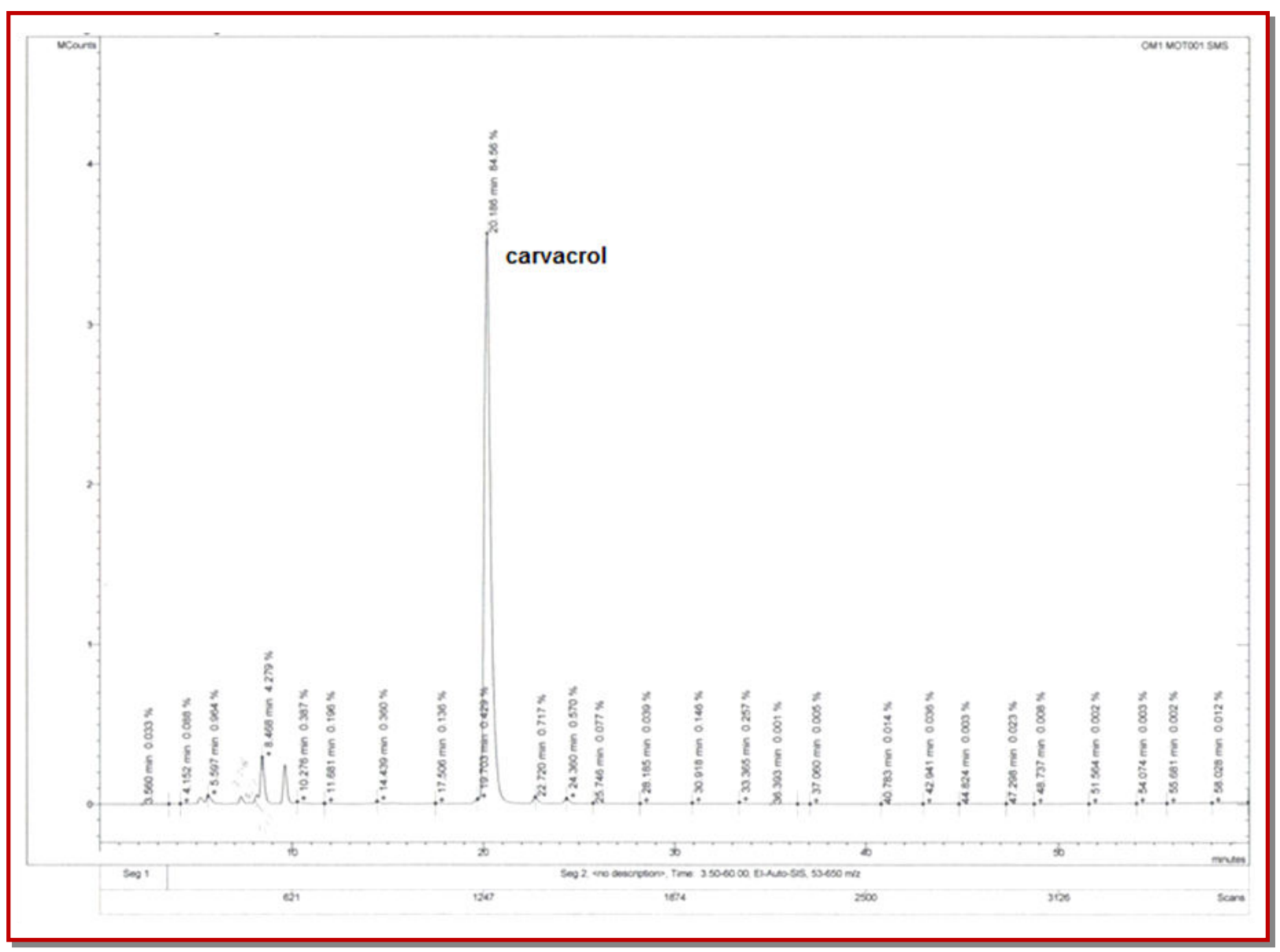

Figure 1: Chromatogram of the essential oil extracted from air-dried leaves of O. ramonense 
Table I

Essential oil composition (\%) of the air-dried leaves of O. ramonense

\begin{tabular}{|c|c|c|c|c|c|}
\hline No. & RT & RI & Compound & $\%$ Area & Mode of identification \\
\hline 1 & 5.6 & 925 & a-Thujene & 0.96 & MS, RI \\
\hline 2 & 7.3 & 991 & $\beta$-Pinene & 0.60 & MS, RI \\
\hline 3 & 7.8 & 1006 & a-Phellandren & $<0.1 \%$ & MS, RI \\
\hline 4 & 8.2 & 1017 & a-Terpinene & 0.60 & MS, RI \\
\hline 5 & 8.5 & 1025 & p-Cymene & 4.28 & MS, RI \\
\hline 6 & 9.6 & 1058 & $\gamma$-Terpinene & 3.30 & MS, RI \\
\hline 7 & 10.3 & 1076 & Cis-Sabinene hydrate & 0.39 & MS, RI \\
\hline 8 & 11.7 & 1113 & Linalool & 0.20 & RI \\
\hline 9 & 14.4 & 1181 & Terpinen-4-ol & 0.36 & MS, RI \\
\hline 10 & 15.3 & 1201 & cis-Dihydrocarvone & 0.15 & RI \\
\hline 11 & 17.2 & 1247 & Carvotanacetone & 0.14 & RI \\
\hline 12 & 18.3 & 1273 & Geranial & $<0.1 \%$ & RI \\
\hline 13 & 19.7 & 1307 & Thymol & 0.43 & MS, RI \\
\hline 14 & 20.2 & 1318 & Carvacrol & 84.56 & MS, RI \\
\hline 15 & 22.7 & 1379 & 5-methoxy-1, 2, 3-trimethylbenzene & 0.72 & MS, RI \\
\hline 16 & 24.4 & 1419 & Caryophyllene & 0.57 & MS, RI \\
\hline 17 & 25.7 & 1453 & a-Humulene & $<0.1 \%$ & MS, RI \\
\hline 18 & 28.2 & 1514 & $\gamma$-Cadinene & $<0.1 \%$ & MS, RI \\
\hline 19 & 30.9 & 1585 & Caryophyllene oxide & 0.15 & MS, RI \\
\hline \multirow[t]{6}{*}{20} & 33.4 & 1651 & $\delta$-Cadinene & 0.26 & MS, RI \\
\hline & & & Total identified & 97.78 & \\
\hline & & & Monoterpenes hydrocarbons & 9.76 & \\
\hline & & & Oxygenated monoterpenes & 86.94 & \\
\hline & & & Sesquiterpene hydrocarbons & 0.94 & \\
\hline & & & Oxygenated sesquiterpenes & 0.15 & \\
\hline
\end{tabular}

Table II

\section{Antibacterial activity of $O$. ramonense EOs} using disc diffusion method

\begin{tabular}{|lcr|}
\hline Bacterial species & $\begin{array}{c}\text { Inhibition } \\
\text { zone }(\mathrm{mm})\end{array}$ & $\begin{array}{c}\text { Ciproflox- } \\
\text { acin }\end{array}$ \\
\hline Escherichia coli & $24.5 \pm 0.5$ & $24.3 \pm 0.6$ \\
Klebsiella pneumoniae & $20.2 \pm 1.6$ & $20.8 \pm 0.8$ \\
Enterobacter aerogenes & $21.3 \pm 0.8$ & $20.5 \pm 0.5$ \\
Pseudomonas aeruginosa & $20.7 \pm 0.3$ & $23.3 \pm 0.6$ \\
Proteus mirabilis & $16.7 \pm 0.3$ & $19.2 \pm 0.28$ \\
Staphylococcus aureus & $26.2 \pm 1.4$ & $22.0 \pm 1.7$ \\
Staphylococcus epidermidis & $28.3 \pm 0.6$ & $22.5 \pm 0.5$ \\
E. coli 25922 & $22.7 \pm 0.6$ & $22.8 \pm 0.8$ \\
P. aeruginosa 10145 & $23.8 \pm 0.8$ & $24.3 \pm 0.6$
\end{tabular}

Each disc contains $3 \mu \mathrm{L}$ of Eos; Ciprofloxacin disc contains $5 \mu \mathrm{g}$
The minimum inhibitory concentrations and minimum bactericidal concentrations of $O$. ramonense essential oil for the tested bacteria indicated that all tested bacterial strains were highly susceptible to $O$. ramonense essential oil. S. aureus, S. epidermidis, K. pneumoniae and E. aerogenes had the lowest minimum inhibitory concentration values $(0.015 \mu \mathrm{g} / \mathrm{mL})$ followed by $E$. coli $(0.14 \mu \mathrm{g} / \mathrm{mL}$; Table III). The lowest susceptible strains to essential oil were P. mirabilis $(1.2 \mu \mathrm{g} / \mathrm{mL})$ and E. coli $25922(11.1 \mu \mathrm{g} /$ $\mathrm{mL}) P$. aeruginosa and the reference strain $P$. aeruginosa 10145 exhibited similar minimum inhibitory concentration values with $11.1 \mu \mathrm{g} / \mathrm{mL}$. In general, the minimum bactericidal concentration and minimum inhibitory concentration values were observed to be equal or close for most of the investigated strains. The exceptions of obtained data for minimum bactericidal concentration were that of $P$. mirabilis and E. aerogenes in which the minimum bactericidal concentration values are 3-fold and 9-fold of the minimum inhibitory 
Table III

Minimum inhibitory concentrations (MICs) and Minimum bactericidal concentrations (MBCs) of $O$. ramonense EOs

\begin{tabular}{|lcc|}
\hline Bacterial species & $\begin{array}{c}\text { MIC } \\
(\mu \mathrm{g} / \mathrm{mL})\end{array}$ & $\begin{array}{c}\mathrm{MBC} \\
(\mu \mathrm{g} / \mathrm{mL})\end{array}$ \\
\hline Escherichia coli & 0.14 & 0.14 \\
Klebsiella pneumoniae & 0.015 & 0.015 \\
Enterobacter aerogenes & 0.015 & 0.14 \\
Pseudomonas aeruginosa & 11.1 & 11.1 \\
Proteus mirabilis & 1.2 & 3.7 \\
Staphylococcus aureus & 0.015 & 0.015 \\
Staphylococcus epidermidis & 0.015 & 0.015 \\
E. coli 25922 & 11.1 & 11.1 \\
P. aeruginosa 10145 & 11.1 & 11.1 \\
MIC and $\mathrm{MBC}$ were determined using a concentration ranged from \\
33.3 to $0.015 \mu \mathrm{g} / \mathrm{mL}$ & \multicolumn{2}{|}{} \\
\hline
\end{tabular}

concentration values, respectively.

\section{Discussion}

In this study, the GC-MS analysis of the O. ramonense essential oil pointed out that ooxygenated monoterpenes $(86.9 \%)$ as the major component with carvacrol as predominate component. Previous analysis of the essential oil from the O. ramonense (Danin et al., 1997) led to the identification of most dominated compounds of $O$. ramonense obtained in this study. These were oxygenated monoterpenes although they were represented by a-terpineol (41.5\%), terpinen-4-o1 $(16.8 \%)$, cis-sabinene hydrate $(13.2 \%)$ and eugenol $(3.6 \%)$. In this study, GC-MS analysis showed a lack of a-terpineol and eugenol while terpinen-4-o1 and cissabinene hydrate were indicated at low concentrations. Furthermore, the major component monitored in this study carvacrol (84.6\%) whereas too lower concentration $(0.1 \%)$ was reported (Danin et al., 1997).

The chemical composition of essential oil of various Origanum species has been determined. Collectively, more than 60 different compounds have been identified. The most frequent compounds identified from Origanum species include carvacrol, $\beta$-fenchyl alcohol, thymol, and $\gamma$-terpinene (Vazirian et al., 2015). For instance, the major compounds of $O$. vulgare essential oil (Teixeira et al., 2013) include carvacrol, thymol, $\gamma$-terpinene, and p-cymene while the main components of $O$. onites essential oil (Ozdemir et al., 2017) include thymol, $\gamma$-terpinene, $p$-cymene, and carvacrol.

Three white-flowered biotypes of $O$. vulgare studied were growing wild in different locations of Italy (De Falco et al., 2014). Their essential oil was rich with either carvacrol or thymol whereas phenols content was the lowest among them. Factors such as genetic makeup, harvesting seasons, geographical distribution and the extraction methods collectively might affect the chemical composition of essential oil (Ozdemir et al., 2017). Chemical analysis of the essential oil from these plants showed a high variability in the essential oil composition and content, indicating that various compounds may account for the different extents of the antimicrobial activity of plants

In this study, our results revealed the potential broad spectrum antibacterial activity of $O$. ramonense essential oil. This potent activity could be because of the presence of its main component carvacrol. The antibacterial potency of carvacrol and its isomer thymol, has been reported with extremely low minimum inhibitory concentration and minimum bactericidal concentration values (Qaralleh et al., 2009; Althunibat et al., 2016). Carvacrol is considered as one of the most bactericidal essential oil components against both Gram positive and Gram negative bacteria (Hammer et al., 1999; Nieto, 2017). Mihajilov-Kristev et al., showed that essential oil (Satureja hortensis) rich in carvacrol $(67 \%)$ and $\gamma$-terpinene $(15 \%)$ are strong bacteriostatic and bactericidal agent against both Gram positive and Gram negative bacteria with low minimum inhibitory concentration and minimum bactericidal concentration values $(0.025-0.78 \mu \mathrm{L} / \mathrm{mL})$ (Mihajilov-Krstev et al., 2010). Other compounds such as p-cymene and gamma terpinene are also known for their antibacterial activity. Nevertheless, the antibacterial mechanism at the cellular and molecular level of oregano essential oil against several bacterial strains were previously reported. For instance, the treatment of E. coli O157:H7 with O. vulgare essential oil caused an increment in the cell membrane permeability and leakage of cell contents (Burt and Reinders 2003). Pseudomonas aeruginosa and $S$. aureus treated with $O$. compactum essential oil suffered from membrane damage (Bouhdid et al., 2009). In addition, oregano EOs and carvacrol have been shown to down-regulate the expression of virulence genes in enterohaemorrhagic Escherichia coli (EHEC) O157:H7 (Mith et al., 2015). The essential oil concentration is largely related issue to species, season of gathering the plant, geographical place, the plant part that is used, and the method of oil extraction (Sakkas and Papadopoulou, 2017).

However, several essential oils extracts from different medicinal plants were previously reported with potent antibacterial activity against urinary tract infection isolates such as E. coli, K. pneumonia, S. aureus, Streptococcus agalactiae, S. epidermidis, Enterococcus faecalis, S. saprophyticus, Enterobacter spp, Shigella spp, Pseudomonas aeruginosa, Proteus mirabilis and Morganella morganii (Amalaradjou and Venkitanarayanan, 2011; Beydokthi et al., 2017; Kumar et al., 2012; Saee et al., 
2016; Susanti et al., 2013). In contrast, essential oil extract of Oregano is not traditionally used to treat urinary tract infection and information about Oregano utilization in treating or controlling urinary tract infection in the literature are rare. Therefore, the results of this study clearly show that $O$. ramonense essential oil can be used to treat the urinary tract infection patients infected with such urinary tract infection causing agents.

\section{Conclusion}

The bacteriostatic and bactericidal effect at concentration as low as $0.015 \mu \mathrm{g} / \mathrm{mL}$ indicated the potent antibacterial activity of $O$. ramonense essential.

\section{Conflict of Interest}

There is no conflict of interest.

\section{Acknowledgements}

The author wishes to thank Dr. Yousef Alheyari (Faculty of Pharmacy, Jordan University, Amman, Jordan) for essential oil analysis. Acknowledgements to Dr. Mohammad Alimoun (Department of Biology, Mutah University, Al-Karak, Jordan) for the hospitality and for providing lab facilities during this research.

\section{References}

Al-Asoufi A, Khlaifat A, Tarawneh A, Alsharafa K, Al-Limoun $\mathrm{M}$, Khleifat K. Bacterial quality of urinary tract infections in diabetic and non-diabetics of the population of Ma'an Province, Jordan. Pakistan J Biol Sci. 2017; 20: 179-88.

Althunibat OY, Qaralleh H, Al-Dalin SYA, Abboud M, Khleifat K, Majali IS, Aldal'in HK, Rayyan WA, Jaafraa A. Effect of thymol and carvacrol, the major components of Thymus capitatus on the growth of Pseudomonas aeruginosa. J Pure Appl Microbiol. 2016; 10: 367-74

Amalaradjou MAR, Venkitanarayanan K. Natural approaches for controlling urinary tract infections. In: Urinary tract infections. Tenke P (ed), In Tech, 2011, pp 227-28.

Bakkali F, Averbeck S, Averbeck D, Idaomar M. Biological effects of essential oils: A review. Food Chem Toxicol. 2008; 46: $446-75$.

Bartoletti R, Cai T, Wagenlehner FM, Naber K, Johansen TEB. Treatment of urinary tract infections and antibiotic stewardship. Eur Urol Suppl. 2016; 15: 81-87.

Bassanetti I, Carcelli M, Buschini A, Montalbano S, Leonardi G, Pelagatti P, Tosi G, Massi P, Fiorentini L, Rogolino D. Investigation of antibacterial activity of new classes of essential oils derivatives. Food Control. 2017; 73: 606-12.

Benelli G, Pavela R, Canale A, Cianfaglione K, Ciaschetti G,
Conti F, Nicoletti M, Senthil-Nathan S, Mehlhorn H, Maggi F. Acute larvicidal toxicity of five essential oils (Pinus nigra, Hyssopus officinalis, Satureja montana, Aloysia citrodora and Pelargonium graveolens) against the filariasis vector Culex quinquefasciatus: Synergistic and antagonistic effects. Parasitol Int. 2017; 66: 166-71.

Beydokthi SS, Sendker J, Brandt S, Hensel A. Traditionally used medicinal plants against uncomplicated urinary tract infections: Hexadecyl coumaric acid ester from the rhizomes of Agropyron repens (L.) P. Beauv. with antiadhesive activity against uropathogenic E. coli. Fitoterapia 2017; 117: 22-27.

Bouhdid S, Abrini J, Zhiri A, Espuny M, Manresa A. Investigation of functional and morphological changes in Pseudomonas aeruginosa and Staphylococcus aureus cells induced by Origanum compactum essential oil. J Appl Microbiol. 2009; 106: 1558-68.

Burt S. Essential oils: Their antibacterial properties and potential applications in foods. A review. Int J Food Microbiol. 2004; 94: 223-53.

Burt SA, Reinders RD. Antibacterial activity of selected plant essential oils against Escherichia coli O157: H7. Lett Appl Microbiol. 2003; 36: 162-67.

Carezzano M, Sotelo J, Primo E, Reinoso E, Paletti Rovey M, Demo M, Giordano W, de las M Oliva M. Inhibitory effect of Thymus vulgaris and Origanum vulgare essential oils on virulence factors of phytopatogenic Pseudomonas syringae strains. Plant Biol. 2017.

Danin A, Ravid U, Umano K, Shibamoto T. Essential oil composition of Origanum ramonense Danin leaves from Israel. J Essent Oil Res. 1997; 9: 411-17.

De Falco E, Roscigno G, Landolfi S, Scandolera E, Senatore F. Growth, essential oil characterization, and antimicrobial activity of three wild biotypes of oregano under cultivation condition in Southern Italy. Ind Crops Prod. 2014; 62: 242-49.

Foxman B. Epidemiology of urinary tract infections: Incidence, morbidity, and economic costs. Am J Med. 2002; 113: 5-13.

Foxman B. Urinary tract infection syndromes: Occurrence, recurrence, bacteriology, risk factors, and disease burden Infect Dis Clin. 2014; 28: 1-13.

Habbadi K, Meyer T, Vial L, Gaillard V, Benkirane R, Benbouazza A, Kerzaon I, Achbani EH, Lavire C. Essential oils of Origanum compactum and Thymus vulgaris exert a protective effect against the phytopathogen Allorhizobium vitis. Environ Sci Pollut Res. 2017; 1-10.

Hammer KA, Carson C, Riley T. Antimicrobial activity of essential oils and other plant extracts. J Appl Microbiol. 1999; 86: 985-90.

Khleifat KM, Abboud MM, Omar SS, Al-Kurishy JH. Urinary tract infection in South Jordanian population. J Med Sci. 2006; 6: 5-11.

Kumar A, Jhadwal N, Lal M, Singh M. Antibacterial activity of some medicinal plants used against UTI causing pathogens. Int J Drug Dev Res. 2012; 4.

Martinelli L, Rosa JM, Ferreira CdSB, Nascimento GMdL, Freitas MS, Pizato LC, Santos WDO, Pires RF, Okura MH, Malpass GRP. Antimicrobial activity and chemical consti- 
tuents of essential oils and oleoresins extracted from eight pepper species. Ciência Rural. 2017; 47.

McLellan LK, Hunstad DA. Urinary tract infection: Pathogenesis and outlook. Trends Mol Med. 2016; 22: 946-57.

Mihajilov-Krstev T, Radnović D, Kitić D, Stojanović-Radić Z, Zlatković B. Antimicrobial activity of Satureja hortensis L. essential oil against pathogenic microbial strains. Arch Biol Sci. 2010; 62: 159-66.

Mith H, Clinquart A, Zhiri A, Daube G, Delcenserie V. The impact of oregano (Origanum heracleoticum) essential oil and carvacrol on virulence gene transcription by Escherichia coli O157: H7. FEMS Microbiol Lett. 2015; 362: 1-7.

Nieto G. Biological activities of three essential oils of the lamiaceae family. Medicines 2017; 4: 63.

O'Brien VP, Hannan TJ, Nielsen HV, Hultgren SJ. Drug and vaccine development for the treatment and prevention of urinary tract infections. Microbiol Spectr. 2016; 4.

Ozdemir N, Ozgen Y, Kiralan M, Bayrak A, Arslan N, Ramadan MF. Effect of different drying methods on the essential oil yield, composition and anti-oxidant activity of Origanum vulgare L. and Origanum onites L. J Food Meas Charact. 2017; 1-6.

Özkan OE, Güney K, Gür M, Pattabanoğlu ES, Babat E, Khalifa MM. Essential oil of oregano and savory: Chemical composition and antimicrobial activity. Indian J Pharm Educ Res. 2017; 51: S205-08

Qaralleh H, Idid S, Saad S, Susanti D, Taher M, Khleifat K. Antifungal and antibacterial activities of four Malaysian sponge species (Petrosiidae). J Med Mycol. 2010; 20: 315-20.

Qaralleh HN, Abboud MM, Khleifat KM, Tarawneh KA, Althunibat OY. Antibacterial activity in vitro of Thymus capitatus from Jordan. Pakistan J Pharm Sci. 2009; 22.

Saee Y, Dadashi M, Eslami G, Goudarzi H, Taheri S, Fallah F. Evaluation of antimicrobial activity of Cuminum cyminum essential oil and extract against bacterial strains isolated from patients with symptomatic urinary tract infection.
Novelty Biomed. 2016; 4: 147-52.

Sakkas H, Papadopoulou C. Antimicrobial activity of basil, oregano, and thyme essential oils. J Microbiol Biotechnol. 2017; 27: 429-38.

Schito GC, Naber KG, Botto H, Palou J, Mazzei T, Gualco L, Marchese A. The ARESC study: An international survey on the antimicrobial resistance of pathogens involved in uncomplicated urinary tract infections. Int $\mathrm{J}$ Antimicrob Agents. 2009; 34: 407-13.

Susanti D, Awang NA, Qaralleh H, Sheikh Mohamed HI, Attoumani N. Antimicrobial activity and chemical composition of essential oil of Malaysian Etlingera elatior (Jack) RM smith flowers. J Essent Oil Bear PL. 2013; 16: 294-99.

Tarawneh KA, Irshaid F, Jaran AS, Ezealarab M, Khleifat KM. Evaluation of antibacterial and anti-oxidant activities of methanolic extracts of some medicinal plants in Northern part of Jordan. J Biol Sci. 2010; 10: 325-32.

Tawaha KA, Alali FQ, Hudaib MM. Chemical composition and general cytotoxicity evaluation of essential oil from the flowers of Anthemis palestina Reut. ex Boiss. growing in Jordan. J Essent Oil Bear PL. 2015; 18: 1070-77.

Teixeira B, Marques A, Ramos C, Serrano C, Matos O, Neng NR, Nogueira JM, Saraiva JA, Nunes ML. Chemical composition and bioactivity of different oregano (Origanum vulgare) extracts and essential oil. J Sci Food Agric. 2013; 93: 2707-14.

Van der Starre WE, Van Nieuwkoop C, Paltansing S, Van't Wout JW, Groeneveld GH, Becker MJ, Koster T, WattelLouis GH, Delfos NM, Ablij HC. Risk factors for fluoroquinolone-resistant Escherichia coli in adults with community-onset febrile urinary tract infection. J Antimicrob Chemother. 2010; 66: 650-56.

Vazirian M, Mohammadi M, Farzaei M, Amin G, Amanzadeh Y. Chemical composition and anti-oxidant activity of Origanum vulgare subsp. vulgare essential oil from Iran. Res J Pharmacogn. 2015; 2: 41-46. 